\title{
Nutritional status, physical performance and functional capacity in an elderly population in southern Brazil
}

\author{
Ana Lúcia Danielewicz ${ }^{1}$, Aline Rodrigues Barbosa ${ }^{2 *}$, Giovâni Firpo Del Duca ${ }^{3}$ \\ ${ }^{1}$ Graduate Program in Nutrition, Federal University of Santa Catarina - Florianópolis, SC, Brazil \\ ${ }^{2}$ Graduate Program in Nutrition, Graduate Program in Physical Education, Federal University of Santa Catarina - Florianópolis, SC, Brazi \\ ${ }^{3}$ Graduate Program in Physical Education, Federal University of Santa Catarina - Florianópolis, SC, Brazil
}

Study conducted in association with the Postgraduate Program in Nutrition of the Federal University of Santa Catarina, Florianópolis, SC, Brazil

Article received: 05/03/13 Accepted for publication: $10 / 12 / 13$

*Correspondence: Departamento de Educação Física Centro de Desportos Universidade Federal de Santa Catarin Campus Trindade Florianópolis, SC - Brazil Phone/Fax: +55 48 3721-9368 aline.r.barbosa@ufsc.br alinerb13@yahoo.com.br

http://dx.doi.org/10.1590/1806-9282.60.03.0013

Conflict of interest: none

\section{SUMMARY}

Nutritional status, physical performance and functional capacity in an elderly population in southern Brazil

Objective: to investigate the association between nutritional status and functional limitation and disability in an elderly population in southern Brazil.

Methods: epidemiological, cross-sectional household-based study carried out with 477 elderly of both sexes (60 to 100 years). Body mass index (BMI) served to assess the nutritional status: underweight $\left(\mathrm{BMI}<22 \mathrm{~kg} / \mathrm{m}^{2}\right)$ and overweight $\left(\mathrm{BMI}>27 \mathrm{~kg} / \mathrm{m}^{2}\right)$. The sum score $(0-5)$ obtained in three tests: "chair stand" and "pick up a pen" (measured by time) and standing balance (four static measurements) assessed the functional limitation. The disability was evaluated by the difficulty in performing one or more self-reported tasks related to basic activities of daily living (ADLs) and instrumental activities of daily living (IADLs). Crude and adjusted analyzes (3 models) were carried out using Poisson regression; prevalence ratios (PR) and 95\% confidence intervals (CI) were calculated.

Results: crude analyzes showed a positive association between underweight and functional limitation ( $\mathrm{PR}=2.71,95 \% \mathrm{CI}=1.63$ to 4.51$)$; overweight and disability in ADLs ( $\mathrm{PR}=2.20$, CI 95\% $=1.44$ to 3.35$)$; overweight and disability in IA$\mathrm{DLs}(\mathrm{PR}=1.56$, CI $95 \%=1.20$ to 2.03). The additional adjustments for gender, age, level of education, living arrangements, current work, cognitive function and number of morbidities reduced the strength of the associations, without changing the statistical strength.

Conclusion: nutritional status is a factor that is independently and positively associated with functional limitation and disability. We recommend the use of this indicator to monitor the health of the elderly.

Key words: aging; nutritional status; activities of daily living; mobility limitation.

\section{INTRODUCTION}

Aging is a complex process with changes in physiological, psychological and social factors that may impact on nutritional status. ${ }^{1}$ Moreover, with advancing age, there is an increase in the number of chronic diseases ${ }^{2}$ and cognitive impairment. ${ }^{3}$ These factors may contribute to changes in motor functions in older people.

Motor function can be assessed by direct and indirect measures that assess different dimensions. Performance tests assess limitations in physiological variables needed for basic physical actions and identify the risk of progression to disability. The measurements obtained by questioning the interviewee identified the disability of individuals to perform certain tasks related to daily activities. These activities can be influenced by sex, perception of the individual and the socio-cultural context. ${ }^{4,5}$ The functional limitations and disabilities are conditions prevalent in the elderly, ${ }^{6-9}$ with implications for increased use of health services and institutionalization, creating a serious public health problem. ${ }^{8,9}$ 
Some studies suggest that nutritional status is an indicator of health and an important factor associated with motor performance limitations $s^{7,10,11}$ and disability relating to basic and instrumental activities of daily life (ADLs and IADLs). ${ }^{11,14}$ However, there are disagreements about whether this association is due to the underweight and/ or overweight obesity status.

The relationship between nutritional status, functional limitations, and disabilities is still little-explored in Brazil's elderly, especially for those in rural areas. Therefore, the objective of this study was to investigate the association between nutritional status and functional limitation and disability in an elderly population in Southern Brazil.

\section{Methods}

This is a cross-sectional study, based on secondary data derived from an epidemiological, population-based household survey carried out in Antônio Carlos, state of Santa Catarina, Southern Brazil (Effectiveness of health policies, physical activity and nutrition of the elderly from the municipality of Antônio Carlos, Santa Catarina). This municipality (7.458 inhabitants) is the biggest producer of vegetables crops in Santa Catarina, and its population is mostly distributed (68.5\%) across small farms..$^{15}$ Antônio Carlos has three teams of the Family Health Program (FHP), which cover the whole municipality. The aim of the FHP is to increase people's access to primary health care.

The study population and sample were previously published ${ }^{16}$ and shall be briefly presented. The study population consisted of all elderly (rural and urban zones) enrolled in the FHP $(n=916)$. All aged 80 and over $(n=$ 134) were evaluated (February to April 2010). For the 60 to 79 years age group ( $\mathrm{n}=782$ ), the sample (60 to 79 years) consisted of 343 elderly, selected by probability sampling, considering each area of the FHS. The stratified sample was not proportional and we used weights for data analysis. The criteria for sample loss were: lack of proxy respondent; elderly away after three visits on alternate days; and lack of access to the residence because the conditions of rural roads.

Data were collected during one home visit (approximately 50 minutes) using a questionnaire (reduced form) of the SABE survey (Health, Well-being and Aging), carried out in seven countries in Latin America and the Caribbean, including Brazil. ${ }^{17}$ The elderly with cognitive impairment had an auxiliary aid or a proxy informant (parent or caregiver) to answer the questions. The performance tests and anthropometric measurements were conducted after the questionnaire during the same visit. The in- terviewers received previous training for instrument testing, refinement, precision and accuracy of the tests and anthropometric measurements.

The ethics committees of the Federal University of Santa Catarina approved the research (Protocol $\mathrm{n}^{\circ}$. 189/09). The participants were informed about the objectives and procedures of the study and signed an informed consent.

BMI assessed the nutritional status, according to the following classification. ${ }^{18}<22 \mathrm{~kg} / \mathrm{m}^{2}=$ underweight; 22 to $27 \mathrm{~kg} / \mathrm{m}^{2}=$ normal range; and $>27 \mathrm{~kg} / \mathrm{m}^{2}=$ overweight . This cut-off is adopted by the Brazilian System of Surveillance for Food and Nutrition. ${ }^{19}$ The weight and height were measured according to standard procedures. ${ }^{20} \mathrm{In}$ case of impossibility or difficulty in obtaining measurements, we used equations for estimating body mass $^{20}$ and height. $^{21}$

Three motor performance tests verified the functional limitation: chair stand, pick up a pen and balance. Before each test, the interviewer explained and demonstrated the task and made sure the same could be done without risk to the elderly. The testing procedures were the same used in the SABE survey ${ }^{22,23}$ and will be described concisely.

- Timed chair stand test: the subjects were asked to fold their hands on the opposite shoulder crossed at the wrists and stand up and sit down five times as quickly as possible. To assess the performance we used the following score: ${ }^{22}>60$ seconds $=0 ;>16$ and $\leq 60$ seconds $=1 ;>10$ and $\leq 16$ seconds $=2 ; \leq 10$ seconds $=3$.

- Timed pick up a pen test: the subjects bent down to pick up a pen. To assess the performance we used the following score: ${ }^{22}>30$ seconds $=0 ;>6$ and $\leq 30$ seconds $=1 ; \geq 2$ and $\leq 6$ seconds $=2 ;<2$ seconds $=3$.

- Balance: the elderly was asked to perform each of the following tasks in sequence (10 seconds): side-by-side stand; full tandem stand; one-leg stand (right); one-leg stand (left). The performance alternatives were: unable $=0$; carried only a side-by-side stand position $=1$; successfully in a side-by-side stand and in a full tandem stand $=2$; if they could hold a one-leg standing position (right, left, or both) $=3$.

A scale, based on the sum of the scores (0 to 9) obtained in the three tests (chair stand, pick up a pen and balance) found functional limitations: with functional limitation (0 to 5) and without functional limitation (6 and more), based on median values.

The elderly who refused to perform the tests or failed to perform them because of poor interpretation or cog- 
nitive problems were excluded from analyzes $(n=4)$. The elderly dependent on wheelchairs, crutches or walkers, with paralysis of the arms or legs, with prosthetic legs and in some that do not maintain balance alone were included $(n=39)$ in the analyzes with score $0 .{ }^{22,23}$

- Disability in basic activities of daily living (ADLs): reported difficulty in one or more of the following tasks: eating, bathing, dressing, going to and using the bathroom, lying down and getting out of bed. Possible responses were: yes/no/does not know/no response. There were no cases of "does not know" or no response. Thus, the variable was dichotomous: yes (dependent - the elderly presented one or more difficulties)/no (independent - elderly had no difficulties in perform any task).

- Disability in instrumental activities of daily living (IADL): reported difficulty in one or more of the following tasks: preparing a hot meal, taking care of their own money, going to places alone, shopping for food, using the phone, doing light tasks, housework, doing heavy household chores and taking medicines. Response alternatives were (yes/no/ does not usually do this/does not know/not response). The elderly who did not know or did not answer the question were excluded $(n=4)$. Those who answered the alternative "does not usually do this", in at least one of the questions, were classified according to the majority of the answers in the other questions, since this alternative is more related to personal habits than to performance difficulties. ${ }^{8}$ We considered the two alternatives: dependent (difficulty performing one or more tasks); and independent (no difficulty to perform any task).

Gender, age, living arrangements (living alone/accompanied); level of education (illiteracy/ 1 year/2 years or more); currently working (yes/no); number of morbidities (0 to $2 / 3$ and more diseases previously diagnosed - hypertension, diabetes, arthritis, osteoarthritis, osteoporosis, respiratory disease, heart disease, stroke, cancer). Cognitive function (normal/altered) was assessed using the Mini-Mental State Examination (MMSE), ${ }^{24}$ according to Bertolucci et al. ${ }^{25}$

\section{Statistical PROCEdURES}

Mean, standard deviation, and proportions made the descriptive analyses of the variables. The association between nutritional status and dependent variables was tested through Poisson's regression (crude and adjusted analysis), adjusting for robust variance.
We proposed three regression models for the association of nutritional status and each dependent variable (functional limitation, disability in ADL and IADL): 1) adjusted for gender and age; 2) adjusted for gender, age, level of education, and current work and living arrangements; 3) adjusted for gender, age, level of education, current job, living arrangements, number of morbidities and cognitive status (final model). Among the adjustment variables, age was a continuous variable in the models, the others were categorical variables.

The analyses were performed using STATA ${ }^{\circledR}$ 11.0. All analyses were weighted for the purpose of the design of the study (post-stratification weight). We adopted a significance level of $5 \%(\mathrm{p} \leq 0.05)$ and a confidence interval of $95 \%(95 \% \mathrm{CI})$.

\section{Results}

The study included 270 women and 207 men, aged between 60 and 100 years $(73.26 \pm 8.87)$. The mean age for men was $73.3 \pm 8.96$ years and for women, $73.2 \pm 8.82$ years.

The majority of elderly living accompanied, was not currently working, had studied one year in elementary school, had normal cognitive status and reported zero to 2 diseases. The prevalence of underweight and overweight were $8.2 \%$ and $53 \%$, respectively. Twenty-four percent $(24 \%)$ of the elderly presented functional limitation, and $43.5 \%$ and $26.4 \%$ of the sample were dependent in IADLs and ADLs, respectively (Table 1).

\section{TABLE 1 Characteristics of the study population} (Antônio Carlos, Santa Catarina, Brazil, 2010)

\begin{tabular}{|c|c|c|c|}
\hline Variable & n & $\%^{a}$ & $95 \% \mathrm{Cl}^{\mathrm{b}}$ \\
\hline \multicolumn{4}{|c|}{ Gender $(n=477)$} \\
\hline Female & 270 & 56.8 & $52.1-61.6$ \\
\hline Male & 207 & 43.2 & $38.4-47.9$ \\
\hline \multicolumn{4}{|c|}{ Living arrangement $(n=477)$} \\
\hline Living alone & 65 & 13.1 & $9.9-16.3$ \\
\hline Accompanied & 412 & 86.9 & $83.7-90.1$ \\
\hline \multicolumn{4}{|c|}{ Currently work $(n=469)$} \\
\hline Yes & 179 & 40.3 & $35.6-45.1$ \\
\hline No & 290 & 59.7 & $54.9-64.4$ \\
\hline \multicolumn{4}{|c|}{ Level of education $(n=476)$} \\
\hline Illiteracy & 90 & 18.2 & $14.6-21.9$ \\
\hline 1 year & 366 & 76.3 & $72.2-80.5$ \\
\hline 2 years or more & 20 & 5.4 & $3.1-7.8$ \\
\hline \multicolumn{4}{|c|}{ Cognitive function $(n=467)$} \\
\hline Normal & 412 & 90.3 & $87.7-93$ \\
\hline Altered & 55 & 9.7 & $7-12.3$ \\
\hline
\end{tabular}


TABLE 1 Characteristics of the study population (Antônio Carlos, Santa Catarina, Brazil, 2010) (continuation)

Number of morbidities $(n=477)$

\begin{tabular}{l|l|l|l}
\hline $0-2$ & 318 & 66.9 & $62.4-71.4$ \\
\hline 3 or more & 159 & 33.1 & $28.6-37.6$ \\
\hline
\end{tabular}

Nutritional status $(n=466)$

\begin{tabular}{l|l|l|l}
\hline Underweight & 47 & 8.2 & $5.7-10.6$ \\
\hline Normal weight & 186 & 38.8 & $34.1-43.5$ \\
\hline Overweight & 233 & 53 & $48.2-57.8$ \\
\hline
\end{tabular}

Functional limitation $(n=473)$

\begin{tabular}{l|l|l|l}
\hline Yes & 123 & 24 & $19.9-28.1$ \\
\hline No & 350 & 76 & $71.9-80.1$ \\
\hline
\end{tabular}

IADL $(n=473)$

\begin{tabular}{l|l|l|l}
\hline Dependent & 218 & 43.5 & $38.7-48.2$ \\
\hline Independent & 255 & 56.5 & $51.8-61.3$ \\
\hline
\end{tabular}

ADL $(n=477)$

\begin{tabular}{l|l|l|l}
\hline Dependent & 125 & 26.4 & $22.2-30.7$ \\
\hline Independent & 352 & 73.6 & $69.3-77.8$ \\
\hline
\end{tabular}

a Percentage of weighted samples.

b $95 \%$ Confidence interval in the weighted sample.

IADL, Instrumental activities of daily living.

$A D L$, Basic activities of daily living.

Table 2 shows the prevalence ratios (PR) of crude and adjusted association between nutritional status and functional limitation. In the crude analysis, there was a positive association between underweight and prevalence of functional limitation ( $\mathrm{PR}=2.71$, CI $95 \%=1.63$ to 4.51 ). The adjustment for age and gender (model 1), level of education, current job, living arrangements (model 2), number of morbidities and cognitive status (final model) did not alter the association significantly although these have contributed to reduce the strength of association. In the final model, the prevalence of functional limitation for the elderly who are underweight was higher $(\mathrm{PR}=2.25$, CI $95 \%$ $=1.35$ to 3.75 ) compared to those with a normal BMI.

Table 3 show crude and adjusted PR between nutritional status and disability in IADLs and ADLs, respectively. In crude analyzes, those who are overweight showed higher prevalence of disability (IADLs and ADLs) compared to those who had a normal BMI. Adjusted analyzes showed that gender and age (model 1) reduced the prevalence, indicating their significance. The same occurred after the inclusion of level of education, current work and living arrangements (model 2), and additional adjustments to cognitive status and number of morbidities (final model). In the final models, overweight remained positively associated with a disability in IADLs ( $\mathrm{PR}=1.46$, CI 95\% $=1.11$ to 1.92 ) and $\mathrm{ADLs}(\mathrm{PR}=2.02$, CI $95 \%=1.33$ to 3.08 ).

\section{Discussion}

The results (final models) showed that underweight was associated with functional limitation and overweight was associated with disability in ADLs and IADLs. The positive associations were independent of gender, age, level of education, current job, living arrangements, cognitive status and number of morbidities.

The association between underweight and functional limitation observed in this study is still controversial. Studies using BMI to assess nutritional status, showed that overweight is more often associated with lowest scores on motor performance tests and/or a greater functional limitation. ${ }^{7,10,12}$

In the Sergi et al. ${ }^{12}$ study, involving elderly (65 to 84 years) of both sexes, moderate and severe obesity was as-

TABLE 2 Prevalence, crude and adjusted analyzes of functional limitation according to the nutritional status of elderly (Antônio Carlos, Santa Catarina, Brazil, 2010)

\begin{tabular}{|c|c|c|c|c|c|c|c|c|c|}
\hline \multirow[t]{3}{*}{ Variable } & \multirow{3}{*}{$\begin{array}{l}\text { Functional } \\
\text { limitation \% }\end{array}$} & \multirow[t]{2}{*}{ Crude analysis } & & \multicolumn{5}{|c|}{ Adjusted analysis } & \\
\hline & & & & Model 1 & & Model 2 & & Model 3 & \\
\hline & & PR (95\% Cl) & $\mathbf{P}$ & PR $(95 \% \mathrm{Cl})$ & $\mathbf{p}$ & PR (95\% Cl) & $\mathbf{p}$ & $\operatorname{PR}(95 \% \mathrm{Cl})$ & $\mathbf{p}$ \\
\hline Nutritional status & & & $<0.001$ & & $<0.001$ & & 0.002 & & 0.009 \\
\hline Normal weight & 15.6 & 1 & & 1 & & 1 & & 1 & \\
\hline Underweight & 42.3 & $2.71(1.63-4.51)$ & & $2.43(1.43-4.12)$ & & $2.40(1.46-3.95)$ & & $2.25(1.35-3.75)$ & \\
\hline Overweight & 23.6 & $1.51(0.99-2.31)$ & & $1.42(0.93-2.19)$ & & $1.38(0.89-2.13)$ & & $1.39(0.89-2.15)$ & \\
\hline
\end{tabular}

$\mathrm{PR}$ (prevalence ratio); $\mathrm{Cl}$ (confidence interval)

Model 1: adjustment for age and gender.

Model 2: adjustment for age, gender, level of education, currently work and living arrangements.

Model 3: adjustment for age, gender, level of education, currently work, living arrangements, cognitive function and number of morbidities. 
TABLE 3 Prevalence, crude and adjusted analyzes of disabilities in instrumental activities of daily living and basic activities of daily living according to the nutritional status of elderly (Antônio Carlos, Santa Catarina, Brazil, 2010)

\begin{tabular}{|c|c|c|c|c|c|c|c|c|c|}
\hline \multirow[t]{3}{*}{ Variable } & \multirow{3}{*}{$\begin{array}{l}\text { Disability } \\
\%\end{array}$} & \multirow[t]{2}{*}{ Crude analysis } & & \multicolumn{5}{|c|}{ Adjusted analysis } & \\
\hline & & & & Model 1 & & Model 2 & & Model 3 & \\
\hline & & $\operatorname{PR}(95 \% \mathrm{Cl})$ & $p$ & $\operatorname{PR}(95 \% \mathrm{Cl})$ & $p$ & $\operatorname{PR}(95 \% \mathrm{Cl})$ & p & $\operatorname{PR}(95 \% \mathrm{Cl})$ & $p$ \\
\hline
\end{tabular}

Instrumental activities of daily living

\begin{tabular}{|c|c|c|c|c|c|c|c|c|c|}
\hline Nutritional status & & & 0.004 & & 0.010 & & 0.020 & & 0.020 \\
\hline Normal weight & 31.5 & 1 & & 1 & & 1 & & 1 & \\
\hline Underweight & 45.1 & $1.43(0.95-2.16)$ & & $1.27(0.85-1.90)$ & & $1.24(0.83-1.84)$ & & $1.15(0.76-1.75)$ & \\
\hline Overweight & 49.2 & $1.56(1.20-2.03)$ & & $1.48(1.14-1.93)$ & & $1.48(1.13-1.93)$ & & $1.46(1.11-1.92)$ & \\
\hline
\end{tabular}

Basic activities of daily living

\begin{tabular}{l|l|l|l|l|l|l|l|l}
\hline Nutritional status & & & 0.001 & & 0.002 & 0.005 \\
\hline Normal weight & 14.4 & 1 & & 1 & & 1 & 0.003 & \\
\hline Underweight & 28.4 & $1.98(1.07-3.64)$ & & $1.87(1.00-3.51)$ & & $1.75(0.93-3.30)$ & $1.69(0.88-3.24)$ & \\
\hline Overweight & 31.5 & $2.20(1.44-3.35)$ & & $2.12(1.40-3.19)$ & & $2.07(1.37-3.14)$ & $2.02(1.33-3.08)$ & \\
\hline
\end{tabular}

PR (Prevalence ratio); $\mathrm{Cl}$ (Confidence interval).

Model 1: adjustment for age and gender.

Model 2: adjustment for age, gender, education, currently work and living arrangements.

Model 3: adjustment for age, gender, education, currently work, living arrangements, cognitive function and number of morbidities.

sociated with motor impairment in mobility tests. However, women with a BMI of $<20 \mathrm{~kg} / \mathrm{m}^{2}$ had more difficulty in the tests, compared to those with adequate BMI (20 to $24.9 \mathrm{~kg} / \mathrm{m}^{2}$ ). Studies that used other methods of nutritional assessment, as the Mini Nutritional Assessment ${ }^{11}$ and the Elderly Nutrition Screening, ${ }^{26}$ the presence of high nutritional risk was related to difficulties in motor performance tests. The differences between the studies appear to be related to differences in the methods of nutritional assessment, the cutoff values used in the BMI classification, age of the elde-rly, environmental characteristics, types of tests used and the way of classification of functional limitation. The higher functional limitation among underweight individuals may be due to the smaller amount of muscle mass, which contributes to lower muscle strength ${ }^{1,10,14}$ and reduced physical activity. ${ }^{10}$ In addition, difficulties in mobility could cause difficulties in food acquisition and meal preparation, negatively affecting the nutritional status. ${ }^{14}$

The results showed that overweight was associated with a higher prevalence of disability in ADLs and IADLs, as verified in other cross-sectional and longitudinal ${ }^{12,13,27}$ studies. Overweight can increase the body burden, limiting movement and increasing the stress on joints and muscles, ${ }^{28}$ accentuating the risk of insufficient physical activity and disability in the elderly, since the implementation of activities may be more difficult due to pain. Furthermore, overweight may be related to greater fat infiltration in skeletal muscle ${ }^{10}$ and the frailty syndrome, ${ }^{27}$ favoring the disability.

Despite the independent and positive associations between underweight and functional limitation and between overweight and disability in ADLs and IADLs, the adjusting for confounding factors attenuated the strength of these associations.

The variables of sex, age, education, living arrangements, current work, morbidities and cognitive status are usually associated with functional limitations, disabilities and nutritional status. Women and older subjects are more fragile and have more chronic diseases..$^{15}$ Women have more body fat than men and those with advancing age, usually after 70 and 75 years, show a greater loss of muscle mass in the limbs, ${ }^{29}$ which may reflect difficulties in routine activities.

Low education level could influence the family income, access to health services and adequate food, resulting in disability ${ }^{30}$ and underweight. ${ }^{31}$ Work can be a way of preserving physical function/muscle, and field work can promote the maintenance of muscle strength, increased energy expenditure and functional independence. ${ }^{32}$ 
Although the condition of living alone can impact on depression and higher nutritional vulnerability, ${ }^{33}$ this seems to be a feature specific to the sociocultural characteristics of the population. ${ }^{34}$ In Antonio Carlos, it was observed that even the elderly who live alone, have family support. Their families live in another house on the same site or very close, and contact with family and community is well preserved.

Functional limitation can precede the onset of cognitive deficit. ${ }^{35}$ In earlier stages of the deficit only tasks of higher complexity are affected and, subsequently, with the progression of dementia the performance of ADL tasks are also affected. ${ }^{36}$

Functional limitations and disabilities result, primarily, from chronic diseases, ${ }^{4}$ and the number of diseases and the interaction between specific diseases, not evaluated in this study, may be important in this relationship. ${ }^{37}$ The higher number of diseases may suggest greater medication use and hospitalizations, which associated with aging, and may result in loss of physical function. ${ }^{38}$

This study has strengths and limitations. To our knowledge (Medline, Scopus, and Scielo database), this is the first study (household based population) that investigated the association between nutritional status, functional limitations and disabilities in elderly living in rural community, in Southern Brazil. We used information from a representative sample suggesting that the results are valid for the target population. Morbidity was reported, as well as measures of disability, which may present an interpretation bias in what respondents have said. Some older people received assistance from proxy during the interview, which may favor the omission of reliable answers. We used a score to classify the motor performance tests (functional limitation), making it impossible to identify in which motor variables (strength, flexibility/mobility and balance) the elderly had more difficulty. The crosssectional design does not establish causality in the associations investigated.

We recommended further prospective studies to assess the nutritional status and its association with measures of motor function in the elderly living in rural areas in order to investigate other factors that may be involved in these associations. The results were presented to Antonio Carlos' Board of Health and Social Assistance and may encourage new prevention policies and health care of the elderly, promoting improvements in nutritional adequacy, functional independence and quality of life of individuals. We believe that the results could be used for prevention policies and health care for elderly from municipalities with similar characteristics.
In conclusion, the nutritional status was positively associated with functional limitations and disability in ADLs and IADLs, despite adjustment for socio-demographic and health variables, confirming that $\mathrm{BMI}$ is an indicator of health that should be used in routine surveillance of health conditions. Adequate nutritional status is important to maintain physical performance and functional capacity.

Acknowledgments: The authors want to thank Antonio Carlos' Board of Health and Social Assistance, the Health Community Agents, and the oldest old attendees on this research. The National Council of Technological and Scientific Development (CNPq-Process 478073/20097) funded the project. Danielewicz received a master's scholarship grant from Coordination of Improvement of Higher Education Personnel (CAPES- REUNI/Postgraduate Program in Nutrition - Federal University of Santa Catarina).

The study was approved by the ethics committee (Comitê de Ética em Pesquisa com Seres Humanos da UFSC; $\mathrm{n}^{\circ}$ $189 / 09)$ in 29/06/2009.

\section{Resumo}

Estado nutricional, desempenho físico e capacidade funcional de uma população de idosos do sul do Brasil

Objetivo: verificar a associação entre estado nutricional, limitação funcional e incapacidade física em idosos da região Sul do Brasil.

Métodos: estudo epidemiológico, transversal, de base populacional e domiciliar, realizado com 477 idosos de ambos os sexos (60 a 100 anos). O estado nutricional foi verificado por meio do índice de massa corporal (IMC): baixo peso (IMC $<22 \mathrm{~kg} / \mathrm{m}^{2}$ ) e excesso de peso (IMC $>27 \mathrm{~kg} / \mathrm{m}^{2}$ ). $\mathrm{Na}$ avaliação da limitação funcional, utilizou-se o somatório dos escores (valores entre 0 e 5 ) dos testes "sentar e levantar" e "pegar o lápis" (avaliados por tempo) e de equilíbrio (quatro medidas estáticas). A incapacidade física foi avaliada pelo relato da dificuldade em realizar uma ou mais tarefas relacionadas às atividades básicas da vida diária (AVD) e às atividades instrumentais da vida diária (AIVD). Foram realizadas análises brutas e ajustadas (3 modelos) usando-se regressão de Poisson (razão de prevalência [RP] e 95\% IC [intervalo de confiança])

Resultados: as análises brutas mostraram associação entre baixo peso e limitação funcional ( $\mathrm{RP}=2,71$; IC 95\% = 1,63-4,51); excesso de peso e incapacidade nas AVD $(\mathrm{RP}=2,2$; IC $95 \%=1,44-3,35)$ e excesso de peso e incapaci- 
dade nas AIVD ( $R P=1.56$; IC 95\% = 1,2-2,03). O ajuste para gênero, idade, nível de escolaridade, arranjo familiar, trabalho atual, função cognitiva e número de morbidades reduziu a magnitude das associações, contudo, sem alterar o poder estatístico.

Conclusão: o estado nutricional é um fator independentemente associado à limitação funcional e à incapacidade. Recomenda-se o uso desse indicador no monitoramento da saúde dos idosos.

Unitermos: envelhecimento; estado nutricional; atividades cotidianas; limitação da mobilidade.

\section{References}

1. Ahmed T, Haboubi N. Assessment and management of nutrition in older people and its importance to health. Clin Interv Aging. 2010;5:207-16.

2. Alves LC, Leimann BCQ, Vasconcelos MEL, Carvalho MS, Vasconcelos AGG, Fonseca TCO et al. A influência das doenças crônicas na capacidade funcional dos idosos do Município de São Paulo. Cad Saúde Pública. 2007;23:1924-30.

3. Raji MA, Kuo YF, Snih SA, Markides KS, Peek MK, Ottenbacher KJ. Cognitive status, muscle strength and subsequent disability in older Mexican American. J Am Geriatr Soc. 2005;53:1462-8.

4. Verbrugge LM, Jette AM. The disablement process. Soc Sci Med. 1994;38:1-14.

5. Guralnik JM, Ferruci L. Assessing the building blocks of function: utilizing measures of functional limitation. Am J Prev Med. 2003;(3 Suppl 2):112-21.

6. Reyes-Ortiz CA, Ostir GV, Pelaez M, Ottenbacher KJ. Cross-national comparison of disability in Latin American and Caribbean persons aged 75 and older. Arch Gerontol Geriatr. 2006;42:21-33.

7. Barbosa AR, Souza JM, Lebrão ML, Marucci MFN. Estado nutricional e desempenho motor em idosos da cidade de São Paulo. Rev Assoc Med Bras. 2007;53:75-9.

8. Santos JL, Lebrão ML, Duarte YA, Lima FD. Functional performance of the elderly in instrumental activities of daily living: an analysis in the municipality of São Paulo, Brazil. Cad Saúde Pública. 2008;24:879-86.

9. Nogueira SL, Ribeiro RCL, Rosado LEFPL, Franceschini SCC, Ribeiro AQ, Pereira ET. Fatores determinantes da capacidade funcional em idosos longevos. Rev Bras Fisioter. 2010;14:322-9.

10. Sergi G, Perissinotto E, Toffanello ED, Maggi S, Manzato E, Buja A et al. Lower extremity motor performance and body mass index in elderly people: the Italian Longitudinal Study on Aging (ILSA). J Gerontol A Biol Sci Med Sci. 2007;55:2023-9.

11. Ferdous T, Cederholm T, Razzaque A, Wahlin A, Nahar Kabir Z. Nutritional status and self-reported and performance-based evaluation of physical function of elderly persons in rural Bangladesh. Scand J Public Health. 2009;37:518-24.

12. Lang IA, Llewellyn DJ, Alexander K, Melzer D. Obesity, physical function, and mortality in older adults. J Am Geriatr Soc. 2008;56:1474-8.

13. Wee CC, Huskey KW, Ngo LH, Fowler-Brown A, Leveille SG, Mittlemen MA et al. Obesity, race and risk for death or functional decline among Medicare beneficiares: a cohort study. Ann Intern Med. 2011;154:645-55.

14. Kikafunda JK, Lukwago FB. Nutritional status and functional ability of the elderly aged 60 to 90 years in the Mpigi district of rural Uganda. Nutrition. 2005;2:59-66.

15. Instituto Brasileiro de Geografia e Estatística. IBGE. Cidades@. [citado 13 fev 2012]. Disponível em: http://www.ibge.gov.br/cidadesat/topwindow. htm?1.

16. Confortin SC, Barbosa AR, Danielewicz AL, Meneghini V, Testa WL. Motor performance of elderly in a community in southern Brazil. Rev Bras Cineantropom Desempenho Hum. 2013;15:417-26.
17. Lebrão ML, Laurenti R. Saúde, bem-estar e envelhecimento: o estudo SABE no município de São Paulo. Rev Bras Epidemiol. 2005;8:127-41.

18. American Academy of Family Physicians. American Dietetic Association, National Council on the Aging. Nutrition screening and intervention resources for healthcare professionals working with older adults. Nutrition Screening Initiative 2002. Washington (DC): American Dietetic Association; 2002.

19. Brasil. Ministério da Saúde. Secretaria de Atenção à Saúde. Departamento de Atenção Básica. Protocolos do Sistema de Vigilância Alimentar e Nutricional - SISVAN na atenção à saúde 2008. Brasília (DF); 2008. (Série B. Textos básicos de saúde).

20. Chumlea WC, Guo S, Roche AF, Steinbaugh ML. Prediction of body weight for the nonambulatory elderly from anthropometry. J Am Diet Assoc. 1988;88:564-8.

21. Chumlea WC, Roche AF, Mukherjee D. Nutritional assessment of the elderly through anthropometry. 2nd ed. Columbus: Ross Laboratories; 1987.

22. Barbosa AR, Souza JM, Lebrão ML, Laurenti R, Marucci MF. Functional limitations of Brazilian elderly by age and gender differences: data from SABE Survey. Cad Saúde Pública 2005;21:1177-85.

23. Rodrigues-Barbosa A, de Miranda LM, Vieira-Guimarães A, Xavier-Corseuil $\mathrm{H}$, Weber-Corseuil M. Age and gender differences regarding performance in the elderly from Barbados and Cuba. Rev Salud Publica (Bogota). 2011;13:54-66

24. Folstein MF, Folstein SE, Mchugh PR. A practical method for grading the cognitive state of patient for the clinician. J Psychiatr Res. 1975;12:189-98.

25. Bertolucci HF, Brucki SMD, Campacci SR, Juliano Y. [The Mini-Mental State Examination in an outpatient population: influence of literacy.] Arq Neuropsiquiatr. 1994;52:1-7.

26. Ávila-Funes JA, Gray-Donald K, Payette H. Association of nutritional risk and depressive symptoms with physical performance in the elderly: the Quebec longitudinal study of nutrition as a determinant of successful aging (NuAge). J Am Coll Nutr. 2008;27:492-8.

27. Chen $\mathrm{H}$, Guo X. Obesity and functional disability among elder Americans. J Am Geriatr Soc. 2008;56:689-94.

28. Niu J, Zhang YQ, Torner J, Nevitt M, Lewis CE, Aliabadi P et al. Is obesity a risk factor for progressive radiographic knee osteoarthritis? Arthritis Rheum. 2008;61:329-35.

29. Barbosa AR, Souza JMP, Lebrão ML, Laurenti R, Marucci MF. Anthropometry of elderly residents in the city of São Paulo, Brazil. Cad Saúde Pública. 2005;21:1929-38.

30. Gjonça E, Tabassum F, Breeze E. Socioeconomic differences in physical disability at older age. J Epidemiol Community Health. 2009;63:928-35.

31. Martín AR, Nieto JMM, Ruiz JPM, Jiménez LE. Overweight and obesity: The role of education, employment and income in Spanish adults. Appetite. 2008;51:266-72.

32. Nelson ME, Rejeski WJ, Blair SN, Duncan PW, Judge JO, King AC et al. Physical activity and public health in older adults: recommendation from the American College of Sports Medicine and the American Heart Association. Circulation. 2007;116:1094-105

33. Kimura Y, Wada T, Okumiya K, Ishimoto Y, Fukutomi E, Kasahara Y et al. Eating alone among community-dwelling Japanese elderly: association with depression and food diversity. J Nutr Health Aging. 2012;16:728-31.

34. Russell D, Taylor J. Living alone and depressive symptoms: the influence of gender, physical disability, and social support among Hispanic and nonHispanic older adults. J Gerontol B Psychol Sci Soc Sci. 2009;64:95-104.

35. Wang L, Larson EB, Bowen JD, van Belle G. Performance based physical function and future dementia in older people. Arch Intern Med. 2006;166:1115--20.

36. Marra TA, Pereira LSM, Faria CDCM, Pereira DS, Martins MAA, Tirado MGA. Avaliação das atividades de vida diária de idosos com diferentes níveis de demência. Rev Bras Fisioter. 2007;11:267-73.

37. Cesari M, Onder G, Russo A, Zamboni V, Barillaro C, Ferrucci L et al. Comorbidity and physical function: results from the Aging and Longevity Study in the Sirente Geographic Area (ilsirente Study). Gerontology. 2006;52:24-32.

38. Puts MT, Deeg DJ, Hoeymans N, Nusselder WJ, Schellevis FG. Changes in the prevalence of chronic disease and the association with disability in the older Dutch population between 1987 and 2001. Age Ageing. 2009;37:187-93. 